\title{
H2AB1 Gene
}

National Cancer Institute

\section{Source}

National Cancer Institute. H2AB1 Gene. NCI Thesaurus. Code C154649.

This gene plays a role in DNA compaction, gene transcription and mRNA processing. 